\title{
Kazakhstan Youth Associations through the Prism of Public Opinion of Young Generation
}

\author{
ZHADYRA KALIYEVA ${ }^{1}$, ALTYNAY ZHURASOVA ${ }^{1}$, NADEZHDA \\ SHAKHMATOVA2, SALIMA UZAKOVA ${ }^{3}$ \\ ${ }^{1} M$. Utemisov West Kazakhstan State University, Uralsk, Kazakhstan \\ Email: Kaliyeva_87@mail.ru; Azhurasova@mail.ru \\ ${ }^{2}$ Saratov National Research State University named after N. G. Chernyshevskiy, Saratov, Russia \\ Email: nadezhdashakhmatova@yandex.ru \\ ${ }^{3}$ Kazakhstan University of Innovation and Telecommunication, Uralsk, Kazakhstan \\ Email: salima1966@mail.ru
}

\begin{abstract}
Results of the sociological studies, performed by means of a questionnaire (quota-area sample), are provided by the authors in the article. It is noted that youth organizations in the modern Kazakhstan are actively developing, playing an increasing role in life of the young generation. Meanwhile, every third young Kazakhstan was undecided during the questionnaire, and this confirms a significant level of inactivity of the most part of the youth. It is emphasized that a disparity between two components of the integration mechanism - youth engagement in one or other structure and identification with them - is observed in terms of social instability and uncertainty. Consequently, integration becomes necessary, more equivalent to mechanical integration than organically established interrelation. There are three approaches in the public opinion of the youth on the development of youth organizations - as a political and ideological structure (dominant), as a social mechanism of socialization, and responses to problems, needs and demands of the youth. Conclusions on a flexible ambiguity and a synthetical nature of the modern youth organizations of Kazakhstan, integrating traditional and paternalistic, and innovation-democratic beliefs and practices, were made on the basis of the performed analysis. And the first dominates over the second ones. At the same time, the youth associations were divided in those, which were created and controlled 'from upstairs' (more according to the youth opinion), and those, which were created upon the initiative 'from below'. It was noted that in the case of orientation to (in the estimation of most people) youth engagement into political life of the society, many organizations solve problems of the society, but not of the youth. Moreover, nowadays most of the modern youth of Kazakhstan considers that the need of young people in public youth organizations has always been a priority. It means applicability and need of modern youth organizations during a troubled period of the society transformation, when young people need support of the society, solution of social problems and assistance, in order to implement themselves and their positive personal qualities, perfect themselves intellectually and spiritually, and to impact on public processes. Also this confirms that the Kazakhstan youth has a considerable potential of public activism.
\end{abstract}

Keywords: youth associations of Kazakhstan, dominant, demand 


\section{INTRODUCTION}

The culture of political youth participation supposes the presence and demand for youth associations, which are a necessary link of personal fulfilment, youth socialization, establishment of a constitutional state and civil society. However, youth consciousness reproduces the political landscape of modern Kazakhstan society and is changed together with them, reflecting all its social and political contradictions.

G. Almond and S. Verba (Almond, Verba, 1992) noted that conflicting objects are set for citizen in a democratic society. The citizen shall be engaged in policy, shall be active, informed, and at the same time sufficiently passive, removed from the policy and respectful towards governing elites. Settlement of this contradiction is based, together with other factors, on the potential, but not real activity of the citizen, their confidence that it can impact on the public process of decision making, if necessary. It means that the share of youth, which does not participate in the political life of youth associations, can be considered as a stability factor of the political system, because it means that young generation does not expect any radical changes on the part of the state. Special attention is paid in Kazakhstan to youth problems, especially within the framework of youth policy: F. E. Alimbetova (Alimbetova 2014), N. A. Ispayev, D. S. Tyulepova (Ispayev, Tyulepova 2012), Z. I. Ashimova (Ashimova 2017), G. O. Abdikerova, B. K. Baiturov (Abdikerova, Baiturov 2017). However, the presence of a substantial deficit of works of Kazakhstan researchers, devoted to the youth and its public associations, shall be stated. Despite the fact that young scientists, the sociologists of Kazakhstan, have created the youth associations within the framework of public life (Abdiraymova 2015), as well as in the process of socialization of the youth of the Republic, they also focus on their functional goals: Sh. Zh. Zhusipkalieva (Zhusipkalieva 2014), A. G. Kialbekova (Kiyalbekova 2014), K. Yu. Lauberts and E. S. Kelbetova (Lauberts, Kelbetova 2017), Z. K. Shaukenova (Shaukenova 2014). However, their fragmentary description can be viewed in separate articles. Despite the relevance of the problem, it should be noted that Kazakhstan researchers have a serious deficit for young people and their public associations.

Scientists from the US and European countries have made a significant contribution to the study of young people and their problems (Smelzer 1994) within the structural-functional direction (Durkheim, Parsons, Eisenstadt, Merton (Merton 1992)), in the channel of routes (symbolic interactionism, ethnometodology, theory of interaction, sociology of daily life, structuralism, etc.) - J. Mead, M. Mead, U. Thomas (Mead 1988).

K. Kenestone and G. Hall, E. Edelman, R. Yusitalo (Giddens 1991) and others showed the phenomenon that youth culture is radically different from other cultures. Today, $21.9 \%$ of the CIS population, $19.6 \%$ of the Russian population and $24.6 \%$ of the total population of the Republic of Kazakhstan have been identified (Statistical Committee CIS, UNFPA, 2016).

\section{RESEARCH METHODS}

A complex of indicators, detecting a paternalistic and innovation-democratic nature, was developed during the investigation of youth associations of the modern Kazakhstan and their operationalization. So, the presence of a managing and executive apparatus, assigned 'from upstairs', a strict control on the part of the organizer (for example, by means of the charter), a clearly defined budget and implementation plan, also developed 'from upstairs', inhibiting initiatives 'from below', lobbyism of an organization at the federal level and the implementation of commercial projects, succession of tasks and directives and the focus on official 
extension of youth engagement into political life of the society can be considered as demonstration of a paternalistic nature of a youth organization. Such features as organization of associations 'from below', i.e. common young citizens in terms of goodwill and initiative, absence of a strict control on the part of the organizer, encouragement of different initiatives on the part of members of the organization, presence or even absence of a managerial and executive apparatus, which was formed on the basis of personal initiatives of members of the organization, i.e. not appointed by 'somebody', innovation and abandon in action plans of the organization, independence during performance and implementation of measures and projects, non-participation in 'political games', lobbying etc., more engagement in life of the society, but not the state, and absence of state support can serve as indicators of an innovation-democratic nature of youth organizations.

The coverage level by youth associations was about $45 \%$ of young Kazakhstan during the questionnaire, for which such participation is promoted by interest to public life, aspiration to development of nature and personal relations, to communication with people. The most popular explanation among those, who do not participate in activity of youth organizations, is time shortage, absence of interest and absence of organization, corresponding to their interests. So, almost every second young Kazakhstan is distinguished by inactivity. Only one in four is interested in political youth organizations or different political forms of social life. Most of known organizations of the modern youth in Kazakhstan are of a social nature, with purposes focused on social assistance and protection of youth, especially studentship and the poor, but not on lobbying of political party interests.

Characterizing the youth organization at the moment of questionnaire, $11.6 \%$ of youth noted that it was created 'from upstairs', i.e. by state or political parties (Table 1). The respondents told almost 2 times more rarely ( $6.7 \%$ of respondents) about the organization of

\section{Table 1. Main characteristics of youth associations of Kazakhstan, $\%$ of respondents}

\begin{tabular}{|c|c|}
\hline Characteristics of youth organization of respondents & $\%$ \\
\hline Organization was created upon initiative 'from upstairs', i.e. by the state or political parties & 11.6 \\
\hline $\begin{array}{c}\text { Organization of this youth association 'from below', i.e. common citizens on the basis of goodwill and } \\
\text { initiative }\end{array}$ & 6.7 \\
\hline Succession in some tasks and directives & 3.5 \\
\hline Independence during implementation of measures and projects & 3.5 \\
\hline Encouragement of different initiatives on the part of members of the organization & 3.2 \\
\hline Clearly defined budget and action plan also developed 'from upstairs' & 2.8 \\
\hline Absence of state support & 2.8 \\
\hline Presence of managerial and executive apparatus, appointed 'from upstairs' & 2.5 \\
\hline Wide youth engagement in political life of the society & 1.8 \\
\hline Appropriate lobbyism at federal level and implementation of commercial projects & 1.4 \\
\hline Absence of strict control on the part of the organizer & 1.4 \\
\hline Non-participation in 'political games', lobbying, etc. & 1.4 \\
\hline More engagement in life of the society, but not of the state & 1.4 \\
\hline Strict control on the part of the organizer (for example, through the charter) & 1.1 \\
\hline
\end{tabular}


Table 1. (Continued)

\begin{tabular}{cc}
\hline Characteristics of youth organization of respondents & $\%$ \\
\hline Initiativity and abandon in action plans of the organization & 1.1 \\
\hline Inhibiting initiative 'from below' & 0.7 \\
\hline $\begin{array}{cc}\text { Presence of managerial and executive apparatus, formed on the basis of personal initiatives of } \\
\text { members of the organization, i.e. not appointed by 'somebody' }\end{array}$ & 0.7 \\
\hline Do not participate & 2.6 \\
\hline Undecided & 49.8 \\
\hline Total & 100.0 \\
\hline
\end{tabular}

their youth association 'from below', i.e. common citizens on the basis of goodwill and initiative. 3.5\% emphasized succession in some tasks and directives of their youth organization, and its independence during implementation of measures and projects. $3.2 \%$ of youth told about encouragement of different initiatives on the part of members of the organization. Just under $2.8 \%$ argued that the budget and action plan of their organization were established 'from upstairs'. But there is the same share of those who complained of the absence of state support $(2.8 \%)$.

$2.5 \%$ of the respondents told that the managerial and executive apparatus of their organization was also appointed 'from above'. $1.8 \%$ of the respondents emphasized that their organization was aimed at formal extension of youth engagement in political life of the society, while $1.4 \%$ indicated engagement in life of the society, but not the state. $1.4 \%$ of the youth indicated that lobbyism existed in their organizations at the federal level and implementation of commercial projects, or vice versa, complained of lobbyism absence, deficit of a strict control on the part of the organizer. $1.1 \%$ told about a very strict control on the part of the organizer (for example, by means of the charter), or emphasized initiativity in action plans of the organization. $0.7 \%$ told about the inhibiting initiative 'from above', or vice versa, on the presence of a managerial apparatus, formed on the basis of personal initiatives of members of the organization, i.e. not appointed by 'somebody'.

So, a quarter of the respondents named such characteristics of their organization, which are more peculiar to a paternalistic traditional nature. Every fifth respondent mentioned characteristics which are focused on the initiative 'from below'. Moreover, $2.6 \%$ refused to characterize their organization as they do not participate anywhere, and almost half of the respondents $(49.8 \%)$ had difficulty with such characteristics, and this proves inactivity, caution of youth statements or deficit of information on work of youth organizations.

When the youth was offered to describe youth organizations in Kazakhstan, every third found it difficult. This is an indirect indicative of a low level of youth awareness on the formation and activity of youth structures. Valid answers were ambivalent and flexible. The opinions are divided by characteristics of youth associations 'from above' (by state or political parties). $28.4 \%$ of the respondents believe that this is typical of all youth structures, $34.4 \%$ consider that this is a feature of only some associations. And only $7.0 \%$ of the respondents are confident that this is absent in any youth organization. Concerning the appointment of a managerial apparatus 'from above', $26.7 \%$ consider this characteristic of all youth organizations, $34.4 \%$ only of some, and $9.1 \%$ of the respondents think that this is absent in any youth organization. A strict control on the part of the organizer (for example, through the charter) is welcomed 
by $15.1 \%$ of the respondents almost in all youth associations. Nearly the same number of the respondents $(16.8 \%)$ consider that this is absent everywhere. However, the opinion that this is typical only of some organizations is met 2 times more often (35.1\%). The clearly defined budget 'from above' and the action plan are peculiar to all youth structures according to the opinion of $22.5 \%$ of the respondents, $37.2 \%$ consider that not to all, and $9.5 \%$ think that to none of youth organizations. The inhibiting initiative 'from below' is typical of all youth organizations. $18.9 \%$ of the respondents think so. $27.7 \%$ consider that this can be related only to some of them. $6.3 \%$ are sure that this is absent in youth organizations.

According to the opinion of $18.6 \%$ of the respondents, lobbyism of youth associations at the federal level and the implementation of commercial projects are peculiar to all similar organizations. However, the opinion that this can be differently is met 2 times more often (32.6\%). 10.5\% consider that this is absent in the Kazakhstan society. A wide engagement of youth into political life, according to the opinion of $29.1 \%$ of men and girls, is welcomed in all such organizations, $33.7 \%$ consider that this is not related to all youth organizations. $9.1 \%$ of the respondents did not notice this in any organization. According to the opinion of $24.2 \%$ of youth, succession in tasks and directives is peculiar to all youth organizations. $33.3 \%$ consider that not to all, and $8.4 \%$ did not notice this.

\section{RESEARCH OUTCOMES}

So, according to the opinion of the most youth, all these paternalistic indicators are somehow peculiar to youth associations: the organization of youth associations 'from above', i.e. by the state or political parties (62.8\% of youth feel this somehow), a wide official youth engagement in political life of the society $(62.8 \%)$, the presence of a managerial apparatus, appointed 'from above' (61.1\%), the clearly defined budget and action plan, also made 'from above' (59.7\%), succession in some tasks and directives (57.5\%), lobbyism at the federal level and implementation of commercial projects $(51.2 \%)$, a strict control on the part of the organizers (50.2\%). This is less related to variable on inhibiting initiatives 'from below', as almost half of the respondents $(47 \%)$ could not make a determination on this matter.

Analysing the opinion of the youth on the indicators of an innovation-democratic nature of youth associations, we can see that every four young Kazakhstan (24,6\%) considers that these organizations were created 'from below', i.e. by common citizens on the basis of goodwill and initiative of the young people (Table 2). $34.0 \%$ consider that this is typical of some similar structures. $9.1 \%$ of the respondents consider that this is not related to any youth organization. $15.4 \%$ of the respondents told that the absence of a strict control on the part of the organizer was typical of all youth structures. 33.0\% consider that this is a property of only some associations. $17.5 \%$ consider that this is not peculiar to similar structures. Encouragement of different initiatives on the part of members of the organization is peculiar to all youth associations. $27.0 \%$ of the respondents think so. However, the surveyed youth feel this not in all similar structures more often $(29.8 \%)$, and $7.7 \%$ consider that this is not practised anywhere. According to the opinion of $16.5 \%$ of the respondents, the presence of a managerial apparatus of the organization, formed on the basis of personal initiatives of the members 'from below', is peculiar to all youth structures. However, the youth consider 2 times more often $(35.8 \%)$ that this is peculiar only to some organizations. $11.2 \%$ consider that this is not practised anywhere. $23.9 \%$ of the respondents consider that innovations and abandon in action plans are typical of all youth organizations. $33.3 \%$ of the youth consider that this is not peculiar to all associations, $10.5 \%$ consider that this is not anywhere. Speaking about their independence during 
Table 2. Main characteristics of youth associations of Kazakhstan, $\%$ by each characteristic

\begin{tabular}{|c|c|c|c|c|c|}
\hline Characteristics of youth organization & 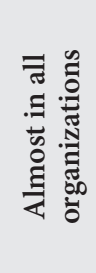 & 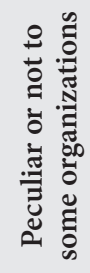 & 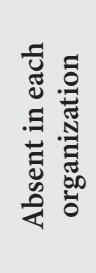 & 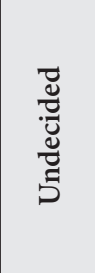 & 苛 \\
\hline $\begin{array}{l}\text { Organization of youth associations from above', i.e. by the state } \\
\text { or political parties }\end{array}$ & $28.4 \%$ & $34.4 \%$ & $7.0 \%$ & $30.2 \%$ & $100.0 \%$ \\
\hline Presence of managerial apparatus, appointed 'from above' & $26.7 \%$ & $34.4 \%$ & $9.1 \%$ & $29.8 \%$ & $100.0 \%$ \\
\hline $\begin{array}{c}\text { Strict control on the part of the organizer (for example, through } \\
\text { the charter) }\end{array}$ & $15.1 \%$ & $35.1 \%$ & $16.8 \%$ & $33.0 \%$ & $100.0 \%$ \\
\hline $\begin{array}{l}\text { Clearly defined budget and action plan also developed 'from } \\
\text { upstairs' }\end{array}$ & $22.5 \%$ & $37.2 \%$ & $9.5 \%$ & $30.9 \%$ & $100.0 \%$ \\
\hline Inhibiting initiative 'from below' & $18.9 \%$ & $27.7 \%$ & $6.3 \%$ & $47.0 \%$ & $100.0 \%$ \\
\hline $\begin{array}{l}\text { Appropriate lobbyism at federal level and implementation of } \\
\text { commercial projects }\end{array}$ & $18.6 \%$ & $32.6 \%$ & $10.5 \%$ & $38.2 \%$ & $100.0 \%$ \\
\hline Wide youth engagement in political life of the society & $29.1 \%$ & $33.7 \%$ & $9.1 \%$ & $28.1 \%$ & $100.0 \%$ \\
\hline Succession in some tasks and directives & $24.2 \%$ & $33.3 \%$ & $8.4 \%$ & $34.0 \%$ & $100.0 \%$ \\
\hline $\begin{array}{l}\text { Organization of associations 'from below', i.e. by common } \\
\text { citizens on the basis of goodwill and initiative }\end{array}$ & $24.6 \%$ & $34.0 \%$ & $9.1 \%$ & $32.3 \%$ & $100.0 \%$ \\
\hline Absence of strict control on the part of the organizer & $15.4 \%$ & $33.0 \%$ & $17.5 \%$ & $34.0 \%$ & $100.0 \%$ \\
\hline $\begin{array}{l}\text { Encouragement of different initiatives on the part of members } \\
\text { of the organization }\end{array}$ & $27.0 \%$ & $29.8 \%$ & $7.7 \%$ & $35.4 \%$ & $100.0 \%$ \\
\hline $\begin{array}{l}\text { Presence or even absence of managerial and executive } \\
\text { apparatus, formed on the basis of personal initiatives of } \\
\text { members of the organizations, i.e. not appointed by 'somebody' }\end{array}$ & $16.5 \%$ & $35.8 \%$ & $11.2 \%$ & $36.6 \%$ & $100.0 \%$ \\
\hline Initiativity and abandon in action plans of the organization & $23.9 \%$ & $33.3 \%$ & $10.5 \%$ & $32.3 \%$ & $100.0 \%$ \\
\hline $\begin{array}{l}\text { Independence during implementation of measures and } \\
\text { projects }\end{array}$ & $29.5 \%$ & $34.0 \%$ & $6.3 \%$ & $30.2 \%$ & $100.0 \%$ \\
\hline Non-participation in 'political games', lobbying, etc. & $15.8 \%$ & $35.4 \%$ & $15.8 \%$ & $33.0 \%$ & $100.0 \%$ \\
\hline More engagement in life of the society, but not of the state & $22.1 \%$ & $36.5 \%$ & $8.8 \%$ & $32.6 \%$ & $100.0 \%$ \\
\hline Absence of state support & $15.4 \%$ & $32.6 \%$ & $16.1 \%$ & $35.8 \%$ & $100.0 \%$ \\
\hline
\end{tabular}

implementation of their measures and projects, $29.5 \%$ noted this as property of all structures, $34.0 \%$ as characteristic of part of youth organizations, and $6.3 \%$ claimed that this is absent everywhere. $15.8 \%$ of the respondents noted non-participation in 'political games', lobbying as a property of all youth associations. However, it was noted 2 times more often (35.4\%) that this is not peculiar to all organizations. $15.8 \%$ consider that this is not peculiar to youth structures.

Engagement of all youth associations in life of the society, but not of the state was emphasized by $22.1 \%$ of the respondents. $36.5 \%$ insisted that this is typical not of all organizations. $8.8 \%$ noted that they did not observe this absolutely. Roughly the same shares of the respondents told about a complete support of all youth organizations on the part of 
the state $(16.1 \%)$ or about its absence (15.4\%). However, they indicated that this was differently in all organizations 2 times more often (32.6\%).

So, according to the opinion of most respondents, independence in the implementation of their measures and projects (63.50\%), organization of associations 'from below', on the basis of the initiative of common citizens (58.60\%), engagement in life of the society, but not of the state (58.60\%), innovations and abandon in action plans (57.20\%), encouragement of different initiatives of their members $(58.60 \%)$, presence of a managerial apparatus, formed on the basis of personal initiatives of the members of the organization 'from below' (52.30\%), non-participation in 'political games' and lobbying (51.20\%) are peculiar to youth organizations. The absence of a strict control on the part of the organizer (48.0\%) and the absence of state support (48.00\%) were mentioned more rarely. Otherwise speaking, most of young people emphasize the preferred innovation-democratic nature of youth associations. However, they are forced to state a strict control on the part of the organizers, which are national and party bodies, what demonstrates a traditional nature of many youth associations.

The respondents were suggested to clarify some aspects of their activity in details (Table 3 ) in order to determine the democratism level of youth associations. So, speaking about

Table 3. Gender distribution of respondents' opinion about the methods of decision making in youth associations of Kazakhstan, $\%$ by gender

\begin{tabular}{c|ccc}
\hline \multirow{2}{*}{ Making decisions in your organization } & \multicolumn{2}{|c|}{ Sex } & \multirow{2}{*}{ Total } \\
\cline { 2 - 3 } & Male & Female & \\
\hline $\begin{array}{c}\text { At the management level of the organization } \\
\begin{array}{c}\text { Suggestions are made, and the management supports/does not support them } \\
\text { in its sole discretion }\end{array}\end{array}$ & $26.0 \%$ & $28.0 \%$ & $27.4 \%$ \\
\hline $\begin{array}{c}\text { Decisions are made together, with the assistance of initiatives by } \\
\text { the management }\end{array}$ & $11.6 \%$ & $10.2 \%$ \\
\hline $\begin{array}{c}\text { Decisions are made by members of the organization, without management } \\
\text { Do not participate in the organization }\end{array}$ & $3.1 \%$ & $13.5 \%$ & $4.2 \%$ \\
\hline Undecided & $19.8 \%$ & $16.9 \%$ & $17.9 \%$ \\
\hline Total & $30.2 \%$ & $25.9 \%$ & $27.4 \%$ \\
\hline
\end{tabular}

making decisions in the organizations, $27.4 \%$ of young people (especially women - $28 \%$ ) emphasized that all decisions are made at the management level. It was indicated that offers were made 'from below', and the management supported/did not support them in its sole discretion 2 times more rarely (10.2\%). Women (11.6\% against $7.3 \%$ of men) insisted on this mostly. $13.0 \%$ of the respondents (especially men $-13.5 \%$ ) insisted that decisions in their organizations were made together, with the assistance of initiatives by the management.

However, only $4.2 \%$ (women more often $-4.8 \%$ ) emphasized that decisions were made by members of the organization, without the management. Moreover, $45.3 \%$ could not (because they do not participate in the organization - 17.9\%) or did not want (because of a low awareness level) to answer this question.

The issue on budget sources of the organization, funds for project implementation was the most difficult for the youth (Table 4). 5.0\% of the respondents could not answer this 
Table 4. Gender distribution of respondents' opinion about the sources of budget of youth associations in Kazakhstan, \% by gender

\begin{tabular}{c|ccc}
\hline \multirow{2}{*}{$\begin{array}{c}\text { Determination of budget of the organization, receipt of funds for } \\
\text { projects implementation }\end{array}$} & \multicolumn{2}{|c}{ Sex } & \multirow{2}{*}{ Total } \\
\cline { 2 - 3 } & Male & Female & \\
\hline Political party to which youth organization is related & $16.7 \%$ & $\mathbf{1 8 . 5 \%}$ & $17.9 \%$ \\
\hline $\begin{array}{c}\text { Management of the organization determines budget and tries to find funds for } \\
\text { projects implementation independently }\end{array}$ & $\mathbf{1 3 . 5 \%}$ & $11.6 \%$ & $12.3 \%$ \\
\hline Charity funds & $8.3 \%$ & $\mathbf{1 1 . 1 \%}$ & $10.2 \%$ \\
\hline Funds as a result of commercial projects implementation & $\mathbf{7 . 3 \%}$ & $4.8 \%$ & $5.6 \%$ \\
\hline Undecided & $54.2 \%$ & $54.0 \%$ & $54.0 \%$ \\
\hline Total & $100.0 \%$ & $100.0 \%$ & $100.0 \%$ \\
\hline
\end{tabular}

question, which is meant to be an indirect indicator of insufficient transparency of budgets of youth organizations.

$17.9 \%$ of the respondents (women more often - 18.5\%) indicated such source of financing as a political party, to which youth organization is related. $12.3 \%$ (men more often $-13.5 \%$ ) emphasized that the management of their organization determines the budget and tries to find funds for project implementation independently. 10.2\% of the respondents (women more often - 11.1\%) named charity funds as sources of financing. 5.6\% (men more often $-7.3 \%$ ) noted that funds appeared as a result of commercial project implementation. So, political parties play the most important role in financing of youth organizations. However, men are more oriented to an independent search of funds, to commercial project implementation, than women.

$34.4 \%$ of the respondents noted the encouragement of the initiative of common members of the organization by senior members of their organization (Table 5). 15.4\% (women more often $-17.5 \%$ ) indicated that such encouragement was only somewhat performed. Only $1.8 \%$ of young people (men more often $-2.1 \%$ ) noted that the initiative of common members of their organization was not encouraged. However, $48.4 \%$ of the respondents evaded the answer.

$36.6 \%$ of the respondents noted that nowadays all youth associations get assistance of the state (Table 6). Women insisted on this particularly (43.4\%). 32.3\% of the young people, especially men $(33.3 \%)$, told that the state did not render assistance to all organizations. Only

Table 5. Gender distribution of respondents' opinion on the encouragement of the initiative of common members of youth associations in Kazakhstan, \% by gender

\begin{tabular}{c|ccc}
\hline \multirow{2}{*}{$\begin{array}{c}\text { Encouragement of the initiative of common members of } \\
\text { the organization by senior members }\end{array}$} & \multicolumn{2}{|c|}{ Sex } & \multirow{2}{*}{ Total } \\
\cline { 2 - 3 } & Male & Female & \\
\hline Yes, initiatives are encouraged & $34.4 \%$ & $34.4 \%$ & $34.4 \%$ \\
\hline Encouraged in some ways & $11.5 \%$ & $\mathbf{1 7 . 5 \%}$ & $15.4 \%$ \\
\hline Are not encouraged & $\mathbf{2 . 1 \%}$ & $1.6 \%$ & $1.8 \%$ \\
\hline Undecided & $52.0 \%$ & $46.5 \%$ & $48.4 \%$ \\
\hline Total & $100.0 \%$ & $100.0 \%$ & $100.0 \%$ \\
\hline
\end{tabular}


Table 6. Gender distribution of respondents' opinion on the state support of youth associations in Kazakhstan, \% by gender

\begin{tabular}{c|c|c|c}
\hline \multirow{2}{*}{ State support of youth organizations } & \multicolumn{2}{|c|}{ Sex } & \multirow{2}{*}{ Total } \\
\cline { 2 - 3 } & Male & Female & \\
\hline Yes, all organizations get state support & $32.3 \%$ & $\mathbf{4 3 . 4 \%}$ & $39.6 \%$ \\
\hline $\begin{array}{c}\text { The state support some organizations, and does not support some } \\
\text { organizations }\end{array}$ & $\mathbf{3 3 . 3} \%$ & $31.7 \%$ & $32.3 \%$ \\
\hline $\begin{array}{c}\text { No, nowadays the state does not support any youth organization } \\
\text { Undecided }\end{array}$ & $\mathbf{6 . 3 \%}$ & $2.6 \%$ & $3.9 \%$ \\
\hline Total & $\mathbf{2 8 . 1} \%$ & $22.3 \%$ & $24.2 \%$ \\
\hline
\end{tabular}

$3.9 \%$ of the respondents insisted that nowadays the state does not render assistance to youth organizations. So, a paternalistic directive of many youth organizations is confirmed. This opinion is popular 2 times more often (6.3\%) among men. $24.4 \%$ of the respondents have some difficulties with this question.

$25.4 \%$ of the respondents indicated such characteristics of their organizations, which were more peculiar to a paternalistic character. $22.2 \%$ mentioned such characteristics, which were focused on the initiative 'from below'. So, speaking about making decisions in organizations, $27.4 \%$ of the young people (especially women - 28\%) emphasized that all decisions were made at the management level. It was indicated that offers were made 'from below', and the management supported/did not support them in its sole discretion 2 times less often (10.2\%). Political parties and state support play an important role in financing of youth organizations. Only a third of the respondents noted the encouragement initiative of common members of the organization by senior members of their organization. Moreover, almost half of the respondents (49.8\%) had difficulties with such characteristics, which is evidence either of inactivity, caution of youth statements, or deficit of awareness about the work of youth organizations.

Speaking about the facts of the activation of youth associations, $34.7 \%$ of the respondents, especially women $-35.4 \%$, consider that the main purpose of youth organizations is support of political ideology of the state (Table 7). $24.6 \%$ of the youth (women more

Table 7. Gender distribution of respondents' opinion on the factors having impact on the development of youth associations of Kazakhstan, \% by gender

\begin{tabular}{c|c|c|c}
\hline \multirow{2}{*}{ What does have impact on development of youth organizations } & \multicolumn{2}{|c|}{ Sex } & \multirow{2}{*}{ Total } \\
\cline { 2 - 3 } & Male & Female & \\
\hline Usage of youth activity for support of political ideology of the state & $33.3 \%$ & $\mathbf{3 5 . 4 \%}$ & $34.7 \%$ \\
\hline State support of social area, particularly public youth organizations & $20.8 \%$ & $\mathbf{2 6 . 5 \%}$ & $24.6 \%$ \\
\hline $\begin{array}{c}\text { Need of youth in such organizations as a result of Kazakhstan society } \\
\text { transformation }\end{array}$ & $11.5 \%$ & $5.3 \%$ & $7.4 \%$ \\
\hline Undecided & $34.4 \%$ & $32.8 \%$ & $33.4 \%$ \\
\hline Total & $100.0 \%$ & $100.0 \%$ & $100.0 \%$ \\
\hline
\end{tabular}


often $-26.5 \%$ ) consider that state support of a social area, particularly of public youth organizations, renders a significant impact on their development. $7.4 \%$ consider need of the youth in such organizations, that appeared as a result of the Kazakhstan society transformation, as the main factor for the development of youth associations. So, there are three approaches to the development of youth organizations in the public opinion of the youth - as a political and ideological structure (dominant), as a social institute, intended to solve its problems, and as response to needs and requests of the youth. Moreover, the fixed $33.4 \%$ of the youth, who did not make a determination by this issue, demonstrate inactivity, political apathy and underdeveloped need in the analysed organizations.

Specification of the youth opinion on the prospects and development rates of youth organizations in the modern Kazakhstan demonstrated that $49.5 \%$ of the respondents $(53.4 \%$ among women and $41.7 \%$ - almost $12 \%$ less, of men) consider that they are developed very actively, and will be developed further, playing a larger role in life of the society (Table 8).

Table 8. Gender distribution of respondents' opinion on the development trends of youth associations of Kazakhstan, \% by gender

\begin{tabular}{|c|c|c|c|}
\hline \multirow{2}{*}{$\begin{array}{c}\text { Development rates of youth organizations in modern Kazakhstan at } \\
\text { present }\end{array}$} & \multicolumn{2}{|c|}{ Sex } & \multirow{2}{*}{ Total } \\
\hline & Male & Female & \\
\hline $\begin{array}{c}\text { Yes, nowadays they are actively developed and will develop further, playing } \\
\text { a larger role in life of the society }\end{array}$ & $41.7 \%$ & $53.4 \%$ & $49.5 \%$ \\
\hline Will develop, depending on state participation in their development & $14.6 \%$ & $6.9 \%$ & $9.5 \%$ \\
\hline Will develop regardless of state policy and support & $7.3 \%$ & $4.8 \%$ & $5.6 \%$ \\
\hline Will develop, but not actively for satisfaction of needs of young citizens & $2.1 \%$ & $2.1 \%$ & $2.1 \%$ \\
\hline They do not develop prospects & $1.0 \%$ & & $0.4 \%$ \\
\hline Undecided & $33.4 \%$ & $32.8 \%$ & $33.0 \%$ \\
\hline Total & $100.0 \%$ & $100.0 \%$ & $100.0 \%$ \\
\hline
\end{tabular}

9.5\% (more often among men - 14.6\%) consider that it will depend on state participation in their development. 5.6\% (more often among men - 7.3\%) consider that they will be developed regardless of the policy and state support. $2.1 \%$ of the respondents noted that they would be developed, but insufficiently active for needs satisfaction of young citizens. Only $1 \%$ of men (women are absent) argue that nowadays there are no development prospects in $0.4 \%$ of organizations. At the same time, each third young Kazakhstan (33.0\%) had difficulties with the answer, and it confirms a significant inactivity level and political apathy of the youth.

Primarily, youth social and political organizations weakly cooperate with the youth and with the state and parties. Many youth organizations do not reflect the real social structure of the society; do not represent interests of the most young people, do not have a clear focus on the solution of youth problems in its activity. Just a traditional/innovation nature of the youth organizations, as a factor of youth participation in them, was two times more critical by the impact on the attitude to them than social and demographic, and social and economic characteristics. 


\section{METHODS AND OBJECTS OF RESEARCH}

The social research 'Youth Association From the Eyes of Young Generation' was conducted in 2016-2017 years by means of a mass questionnaire of the Kazakhstan youth in Uralsk city, which is a typical region of the country. 570 people were surveyed by a quota-area sample. The selection criteria were age, sex and place of residence. The analysis of quantitative empiric sociological information was performed using the package of statistical processing SPSS for Windows 19. Particularly, the methods of one- and multidimensional analysis (construction of cross tables, correlation analysis) were applied.

\section{RESEARCH RESULTS AND THEIR DISCUSSION}

The results of the questionnaire demonstrated that youth organizations in the modern Kazakhstan are actively developed and will develop further, playing a larger role in life of the young generation. At the same time, each third young Kazakhstan was undecided, and this once more confirms a significant level of inactivity of the most youth. A disparity between two components of the integration mechanism - youth engagement in one or other structures and identification with them - is observed in the context of social instability and uncertainty. Consequently, integration becomes necessary, more equivalent to mechanical integration than organically established interrelation. There are three approaches in the public opinion of the youth to development of youth organizations - as a political and ideological structure (dominant), a social mechanism of socialization, and response to problems, needs and demands of the youth.

The conclusions on the flexible ambiguity and synthetical nature of modern youth organizations of Kazakhstan, integrating traditional and paternalistic and innovation-democratic beliefs and practices, were made on the basis of the performed analysis. And the first dominates over the second ones. Youth associations can be divided in those, which were created and controlled 'from upstairs' (according to the youth opinion, there are more such associations), and those, which were created upon the initiative 'from below'. It shall be noted that in the case of the focus (according to the opinion of the most respondents) on youth engagement into political life of the society, many organizations solve problems of the society, but not of the youth.

Moreover, nowadays most of the modern youth of Kazakhstan consider that need of the youth in public youth organizations is in the past and present. It means applicability and need of modern youth organizations during the troubled period of the society transformation, when young people need support of the society, solution of social problems and assistance, in order to implement themselves, their positive personal qualities, perfect themselves intellectually and spiritually, and to impact on public processes. Also this confirms that the Kazakhstan youth has a considerable potential of public activism.

According to the opinion of the youth organizations, political participation of the youth shall be developed only in several areas. Firstly, this is social policy, which arises from mutual relations of the citizen and the state and stipulates the youth participation in the formation and change of rules, and improvement of their life and of the whole society, and this assumes participation in legislative activity, in assistance to the state during the solution of social and economic, cultural and other tasks. Secondly, as state activity, it shall be characterized by alternation of power, transparency of institutes, and possibilities of civil participation, control and impact of youth. Thirdly, the state shall determine common trends of youth policy and 
cooperate with youth organizations on an equal basis, support them, but shall not determine a procedure of formation and shall not create specialized structures 'from above. Only independent youth associations can develop skills of self-organization of youth, provide possibilities for self-actualization and the initiativity of young Kazakhstan.

Received 6 September 2019

Accepted 15 November 2019

\section{References}

1. Abdikerova, G. O.; Baiturov, B. K. 2017. 'Youth in the Social Structure of the Kazakh Society: The Social Status and Problems', Bulletin of KAZNU. Series of Psychology and Sociology 3(62). Available at: https://bulletin-psysoc.kaznu.kz/index.php/1-psy/article/view/558 (accessed: 01.06.2017).

2. Abdraiymova, G. S. 2015. 'Social Condition of Youth: Search for Problem Zones', Bulletin of KAZNU. Series of Psychology and Sociology 54(3). Available at: https://bulletin-psysoc.kaznu.kz/index.php/1-psy/ article/view/161 (accessed: 06.08.2017).

3. Alimbetova, F. E. 2014. 'Development Trends in the Youth Policy in the Republic of Kazakhstan', Bulletin of the Innovative University of Eurasia 1: 46-51.

4. Almond, G. A.; Verba, S. 1992. 'Citizenship Culture and Stability of Democracy', Political Research 4: 124 .

5. Ashimova, Z. I. 2017. 'Problems of Development of Youth Policy in the Republic of Kazakhstan', in Materials of the International Scientific and Practical Conference 'Promoting Competitiveness of National Economy in the Frames of the EAEU'. Part III. Uralsk: WKITU Publishing House, 121-126.

6. Giddens, E. 1991. Sociology. Textbook. Chelyabinsk. 260 p.

7. Ispayev, N. A.; Tyulepova, D. S. 2012. 'Problems of Formation and Realization of the Youth Policy of Kazakhstan, Scientific Community of Students of the XXI Century', in Social Sciences: Collection of Articles Based on the Materials of the VI International Student Scientific and Practical Conference 6. Available at: https: sibac.info/archive/social/6.pdf (accessed: 29.09.2017).

8. Kialbekova, A. G. 2014. 'On the Issue of the Functionality of Youth Organizations in Kazakhstan', in Materials of the 2nd Forum of Young Sociologists of Kazakhstan (in the framework of the V Congress of Kazakhstan Sociologists 'Strategy "Kazakhstan-2050: Social Development of Society" and the V Congress of Sociologists of Turkic-speaking Countries 'National Strategies for the Development of Turkic-speaking Countries'). Almaty, 481-484.

9. Lauberts, K. Yu.; Kelbetova, E. S. 2017. 'The Development of Public Associations in Kazakhstan and Their Status at Present', in Materials of the International Scientific-practical Conference 'Improvement of Competitiveness of National Economies in Frames of the EAEU'. Part III. Uralsk: WKITU Publishing House, 233-238.

10. Mead, M. 1988. The Culture of Childhood. Selected Works. P. 201.

11. Merton, R. 1992. 'Social Structure and Anomie', Sociological Research 2: 5.

12. Smelzer, N. 1994. Sociology. P. 94-130.

13. Social Activity of Modern Kazakhstan in Modern Social and Political Realities. Collective Monograph, under the general editorship of Z. K. Shaukenova. 2014. Almaty: Institute of Philosophy, Political Science and Religious Science Committee MES RK, 168.

14. Youth in the Commonwealth of Independent States: Statistical Portrait. 2016. Statistical Committee CIS, UNFPA. P. 17.

15. Zhusipkalieva, Sh. S. 2014. 'The State and Prospects of Development of the Youth Social Movement in the Republic of Kazakhstan', in Materials of the 2nd Forum of Young Sociologists of Kazakhstan (in the framework of the V Congress of Kazakhstan Sociologists 'Strategy "Kazakhstan-2050: Social Development of Society" and the V Congress of Sociologists of Turkic-speaking Countries 'National Strategies for the Development of Turkicspeaking Countries'). Almaty, 453-459. 
ZHADYRA KALIYEVA, ALTYNAY ZHURASOVA, NADEZHDA SHAKHMATOVA, SALIMA UZAKOVA

\title{
Kazachstano jaunosios kartos nuomonè apie jaunimo asociacijas
}

\begin{abstract}
Santrauka
Pateikiami Kazachstano jaunosios kartos apklausos apie jaunimo asociacijas sociologinio tyrimo rezultatai. Šiuolaikiniame Kazachstane jaunimo organizacijos aktyviai plečiasi ir jaunimo gyvenime vaidina vis didesnị vaidmenį. Tačiau, kaip atskleidè tyrimas, kas trečias apklaustasis nèra apsisprendęs dèl dalyvavimo jaunimo organizacijų veikloje, ir tai rodo dideli jaunimo pasyvumą. Ryškeja neatitikimas tarp dviejų integracinio mechanizmo komponentų - jaunimo ịtraukimo ị vieną ar kitą struktūrą ir identifikacijos su jomis. Tai apibūdinama socialinio nestabilumo ir neapibrèžtumo sąvokomis. Todèl integracija yra labiau mechaninès integracijos ekvivalentas nei organiškai pasiekta tarpusavio sąveika. Išsiskiria trys jaunimo požiūrio ị jaunimo organizacijų plètojimą kryptys: dominuojantis požiūris - tai politinè ir ideologine struktūra; jaunimo socializacijos mechanizmas bei reagavimas ị jaunimo problemas, poreikius ir reikalavimus. Išvados apie šiuolaikinio Kazachstano jaunimo organizacijų nevienareikšmiškumą ir „dirbtinę” prigimtį, apie tradicinių, paternalistinių, inovacinių, demokratinių įsitikinimų ir prakti$\mathrm{kų} \mathrm{integraciją} \mathrm{buvo} \mathrm{gautos} \mathrm{atlikus} \mathrm{antrinę} \mathrm{analizę.} \mathrm{Dominuoja} \mathrm{tradiciniai} \mathrm{įsitikinimai} \mathrm{ir}$ praktikos. Jaunimo asociacijas galima suskirstyti ị dvi grupes: (1) kurios buvo ịkurtos ir kontroliuojamos „iš viršaus“ (tokių, jaunimo nuomone, yra daugiau) ir (2) kurios buvo inicijuotos „iš apačios“. Pastebèta, kad daug organizacijų sprendžia visuomenès, bet ne jaunimo problemas. Dauguma apklaustųjų mano, kad jaunimo organizacijos turètų tenkinti jaunimo poreikius. Tai ypač aktualu visuomenès transformacijos laikotarpiu, kai jaunimas, siekiantis realizuoti save, tobulina savo asmenines savybes, ugdo intelektualinị ir dvasinį potencialą, padeda visuomenei spręsti socialines problemas, daro ịtaką visuomenès procesams. Tai rodo, kad Kazachstano jaunimas turi dideli politinio aktyvumo potencialą.
\end{abstract}

Raktažodžiai: Kazachstano jaunimo asociacijos, dominantè, poreikis 